\title{
KAJIAN KUALITAS AIR SUMUR GALI KAMPUNG UJUNG, LABUAN BAJO, MANGGARAI BARAT
}

\author{
Daniel Wolo', Anna S. Rahmawati², Melania Priska² \\ 1) Program Studi Pendidikan Fisika, Fakultas Ilmu Keguruan dan Pendidikan, \\ Universitas Flores Jl. Sam Ratulangi, Ende 86316, East Nusa Tenggara Indonesia \\ 2) Program Studi Pndidikan Biologi, Fakultas Ilmu Keguruan dan Pendidikan, \\ Universitas Flores Jl. Sam Ratulangi, Ende 86316, East Nusa Tenggara Indonesia \\ E-mail: dewolochem@gmail.com
}

\begin{abstract}
Study of Water Quality Dugs Well at Ujung Village, Labuan Bajo, Manggarai Barat. This preliminary study aims to determine the quality of shallow water in the area of Kampung Ujung, Komodo District, Labuan Bajo City, West Manggarai Regency in September 2019. Sampling technique using the Purposive Sampling technique that is a determination technique with specific considerations with the number of two-point sampling points. The results of the analysis of physical and chemical testing of shallow water samples from two locations indicate that several parameters are exceeding the Class I Water Quality threshold that it can be a conclusion that the quality of 2 shallow water in Kampung Ujung Labuan Bajo area is not suitable to be used as raw material for water drink.
\end{abstract}

Keywords: Kampung Ujung; Labuan Bajo; Water Quality Standard I; Well Quality Standard

\begin{abstract}
Abstrak: Kajian Kualitas Air Sumur Gali Kampung Ujung, Labuan Bajo, Manggarai Barat. Penelitian awal ini bertujuan untuk mengetahui kualitas air sumur gali di wilayah Kampung Ujung, Kecamatan Komodo, Kota Labuan Bajo, Kabuaten Manggarai Barat pada bulan September 2019. Teknik penentuan pengambilan sampel (teknik sampling), menggunakan teknik Purposive Sampling yaitu teknik penentuan dengan pertimbangan tertentu dengan jumlah titik pengambilan sampel dua titik. Hasil analisis pengujian sampel air sumur gali secara fisika dan kimia dari dua lokasi sumur menunjukkan ada beberapa parameter melampaui ambang batas Baku Mutu Air Kelas I sehingga dapat disimpulkan bahwa kualitas pada 2 air Sumur gali di wilayah Kampung Ujung Labuan Bajo kurang layak dimanfaatkan sebagai bahan baku air minum.
\end{abstract}

Kata Kunci: Kualitas Air Sumur; Kampung Ujung; Labuan Bajo; Baku Mutu Air

\section{PENDAHULUAN}

Kampung Ujung adalah salah satu wilayah yang termasuk dalam Kecamatan Komodo, Kota Labuan Bajo, Kabupaten Manggarai Barat. Meningkatnya jumlah penduduk serta aktivitas Pariwisata di Kampung Ujung dalam beberapa tahun terakhir telah memberikan dampak yang besar terhadap perubahan kualitas lingkungan, khususnya lingkungan perairan. Pembangunan fasilitas wisata seperti Taman Kuliner, Minimarket, Hotel dan Mall cukup berpotensi untuk memberikan kontribusi terhadap pencemaran air tanah ${ }^{[1]}$.

Dari hasil pemantauan di lapangan, pola pemukiman masyarakat Kampung Ujung adalah memusat pada satu area dan polanya tidak teratur. Sebagian rumah ada yang berdempetan dengan hotel-hotel, cafe, atau rumah makan yang baru dibangun. Dengan meningkatnya jumlah penduduk dan aktivitas pariwisata tentu akan menuntut kebutuhan air yang semakin besar[2]. Sementara sumber air yang digunakan sehari-hari (mandi, cuci, kakus) dan Industri Pariwisata bersumber dari sumber air tanah dan PDAM. Dari hasil wawancara dengan warga yang sering memanfaatkan air sumur gali, diperoleh fakta pada musim tertentu air sumur tidak dapat digunakan karena berbau dan terasa sangat asin. Sumur gali yang terdapat di Kampung Ujung termasuk tipe sumur dangkal $(<20 \mathrm{~m})$, pembuatan yang murah dan mudah, menyebabkan sumur gali 
banyak digunakan masyarakat. Akan tetapi sumur gali mempunyai resiko pencemaran yang cukup tinggi berupa pencemaran fisik dan kimia dan bakteriologis ${ }^{[3][4] \text {. }}$

Air yang layak minum memiliki aturan dengan syarat standar fisika, kimia dan bakteriologis yang telah ditetapkan. Penggunaan konsumsi air minum yang tidak memenuhi standar kualitas dapat menimbulkan gangguan kesehatan baik secara langsung atau tidak langsung dan secara perlahan (akumulasi waktu). Air tanah dangkal pada sumur gali berpotensi untuk menyerap polutan[5]. Polutanpolutan tersebut berasal dari hasil perembesan air permukaan seperti air hujan yang terakumulasi dengan air sumur. Pada pemukiman padat penduduk, pencemaran air tanah juga disebabkan karena kurang tersedianya lahan untuk pembuatan septi tank, sehingga polutan akan mengalir bersama air hujan menuju badan air[6].

Lokasi Kampung Ujung yang berada di dekat pantai juga menyebabkan adanya intrusi air laut, selain itu adanya aktivitas perhotelan, rumah makan dan taman kuliner jika tidak dikontrol pembuangan sampah organiknya akan menyebabkan pembusukan sampah organik pada saluran air sehingga menjadi bau dan sarang penyakit[7].

Antisipasi tingkat pencemaran air tanah perlu dilakukan melalui pemantauan secara berkala dan berkelanjutan. Langkah awal yang harus dilakukan adalah mengumpulkan data awal terutama data kualitas air yang dipantau. Pengumpulan data ini melaui suatu studi analisis kualitas air baik dilapangan (in-situ) atau di laboratorium (ex-situ). Melalui pemantauan kualitas air ini diharpakan dapat mendeteksi dan mengukur pengaruh yang ditimbulkan oleh suatu pencemar akibat adanya peningkatan aktivitas manusia dan mengetahui gambaran kualitas air pada suatu tempat secara umum.

\section{BAHAN DAN CARA PENELITIAN}

Penelitian ini dilakukan pada air sumur gali dengan dua titik lokasi pengambilan sampel pada area pemukiman warga Kampung Ujung, Labuan Bajo. Penelitian ini dilaksanakan pada bulan September 2019. Teknik penentuan sampling menggunakan teknik purposive sampling dengan pertimbangan air sumur sering digunakan sebagai air minum, mandi, cuci, letak sumur dari sumber pencemar lain, dan pemilik sumur bersedia sumurnya untuk dijadikan sampel. Titik pertama (I) dilakukan pengambilan pada sumur gali yang digunakan sekitar 8-10 keluarga. Pengambilan sampel dilakukan pada pagi hari sebelum ada aktivitas warga. Sampel yang diambil dimasukkan dalam botol yang steril berwarna hitam, botol juga dibilas sebanyak 3 kali dengan sampel air.

Titik 1: Letak sumur gali (I) berada ditengah pemukiman yang padat dan disekitar sumur terdapat aktivitas mencuci piring, kamar mandi, dan air limpasan dari perumahan. Jarak sumur ke pinggir pantai sekitar 75 meter, koordinat (-8.488537, 119.877039 / 8²9'18.7"S 11952'37.3"E). Titik 2: Sumur gali (II) digunakan sekitar 45 keluarga, jarak sumur ke pinggir pantai sekitar 100 meter, jarak dari sumur I ke sumur II sekitar 100 meter, koordinat ($8.489210,119.876487$ / $\quad 8^{\circ} 29^{\prime} 21.2 " \mathrm{~S}$ $\left.119^{\circ} 52^{\prime} 35.4 " \mathrm{E}\right)$

Pada penelitian kualitas air ini, tidak semua parameter dan sifat-sifat air yang akan diteliti. Penelitian ini lebih ditekankan terhadap parameter yang berhubungan dengan keamanan, penerimaan dan fungsi perairan tersebut. Untuk analisis kualitas air dapat dilakukan dengan dua cara yaitu secara langsung di lokasi dan cara pengawetan yang dilakukan di Laboratorium.

Hasil analisis Laboratorium akan dibandingkan dengan Baku Mutu Air Kelas I sesuai peraturan pemerintah Peraturan Pemerintah Republik Indonesia Nomor 82 Tahun 2001 tentang Pengelolaan Kualitas Air dan Pengendalian Pencemaran Air ${ }^{[8]}$.

\section{HASIL PENELITIAN DAN PEMBAHASAN}

Penelitian ini dilakukan pada bulan September 2019, dimana tingkat curah hujan di kota Labuan Bajo sudah mulai menurun. Alasan pemilihan Kampung Ujung karena wilayah ini merupakan salah 
satu destinasi wisata kuliner yang terkenal dan paling ramai dikunjungi, selain itu terdapat pemukiman warga yang cukup padat. Beberapa fasilitas wisata juga terus dibangun di wilayah tersebut seperti hotel, restoran, minimarket dan sebuah mall. Dari hasil pengujian sampel air tanah (sumur gali) menunjukkan beberapa parameter melampaui baku mutu yang ditetapkan Pemerintah yaitu : TDS, DO, Nitrat dan Nitrit dan untuk parameter Nitrogen Amonia hampir melampui standar baku.

Tabel 1. Hasil Pengukuran Kualitas Air Sumur Dangkal di Kampung Ujung

\begin{tabular}{|c|c|c|c|c|c|c|c|}
\hline \multirow{2}{*}{ No. } & \multirow{2}{*}{ Parameter } & \multirow{2}{*}{ Satuan } & \multicolumn{2}{|c|}{ Hasil Pengujian } & \multirow{2}{*}{ Spesifikasi Metode } & \multirow{2}{*}{$\begin{array}{l}\text { Baku } \\
\text { Mutu }\end{array}$} & \multirow{2}{*}{ Keterangan } \\
\hline & & & Sumur 1 & Sumur 2 & & & \\
\hline \multirow[t]{3}{*}{1.} & Suhu & ${ }^{\circ} \mathrm{C}$ & 29.94 & 29,52 & Termometrich & Suhu & Baku Mutu \\
\hline & & & & & & Udara & Permenkes RI \\
\hline & & & & & & \pm 3 & No.32 Tahun \\
\hline \multirow[t]{2}{*}{2.} & $\mathrm{Bau}$ & & Tidak & & Organoleptik & & 2017 Tentang \\
\hline & & & Berbau & & & & Standar Baku \\
\hline 3. & Kekeruhan & NTU & 0,47 & 0,72 & Turbidimetri & 25 & Mutu \\
\hline \multirow[t]{5}{*}{4.} & Zat Padat & $\mathrm{mg} / \mathrm{L}$ & 13115 & 1736 & SNI 06-6989.27- & 1000 & Kesehatan \\
\hline & Terlarut & & & & 2005 Cara Uji Kadar & & Lingkungan \\
\hline & (TDS) & & & & Padatan Terlarut & & dan \\
\hline & & & & & Total Secara & & Persyaratan \\
\hline & & & & & Gravimetri & & Kesehatan Air \\
\hline \multirow[t]{9}{*}{5.} & Residu & $\mathrm{mg} / \mathrm{L}$ & 0,02 & 0,02 & SNI 06-6989.27- & 50 & untuk \\
\hline & Tersuspensi & & & & 2005 Cara Uji Kadar & & Keperluan \\
\hline & (TSS) & & & & Padatan Terlarut & & Higiene \\
\hline & & & & & Total Secara & & Sanitasi, \\
\hline & & & & & Gravimetri & & Kolam Renang, \\
\hline & & & & & & & Solus per \\
\hline & & & & & & & Aqua, dan \\
\hline & & & & & & & Pemandian \\
\hline & & & & & & & Umum \\
\hline \multirow[t]{2}{*}{6.} & Kesadahan & $\mathrm{mg} / \mathrm{L}$ & 0,39 & 0,75 & Spectrofotometric & 500 & PP No. 82 \\
\hline & Total & & & & Hach & & Tahun 2001 \\
\hline \multirow[t]{6}{*}{7.} & $\mathrm{pH}$ & & 6,9 & 7,5 & SNI 06-6989.11- & $6,5-8,5$ & Tentang \\
\hline & & & & & 2004 Cara Uji & & pengelolaan \\
\hline & & & & & Derajat Keasaman & & Kualitas Air \\
\hline & & & & & Dengan & & \\
\hline & & & & & Menggunakan pH & & Pengendalian \\
\hline & & & & & Meter & & Pencemaran \\
\hline 8. & Nitrat & $\mathrm{mg} / \mathrm{L}$ & 12 & 8 & $\begin{array}{l}\text { Spectrofotometric } \\
\text { Hach }\end{array}$ & 10 & Air \\
\hline 9. & Nitrit & $\mathrm{mg} / \mathrm{L}$ & 0,4 & 2,2 & $\begin{array}{l}\text { Spectrofotometric } \\
\text { Hach }\end{array}$ & 1 & \\
\hline 10. & Sulfat & $\mathrm{mg} / \mathrm{L}$ & 62 & 54 & $\begin{array}{l}\text { Spectrofotometric } \\
\text { Hach }\end{array}$ & 400 & \\
\hline \multirow[t]{5}{*}{11.} & DO & $\mathrm{mg} / \mathrm{L}$ & 3,3 & 3,9 & SNI 06-6989.14- & 4 & \\
\hline & & & & & 2004 Cara Uji Kadar & & \\
\hline & & & & & Padatan Terlarut & & \\
\hline & & & & & Total Secara & & \\
\hline & & & & & Gravimetri & & \\
\hline \multirow[t]{2}{*}{12.} & Nitrogen & $\mathrm{mg} / \mathrm{L}$ & 0,45 & 0,01 & Spectrofotometric & 0,5 & \\
\hline & Amonia & & & & Hach & & \\
\hline \multirow[t]{2}{*}{13.} & T. Colli & $\mathrm{CFU} / 100$ & 29 & 11 & ALT & 50 & Baku Mutu \\
\hline & & $\mathrm{mL}$ & & & & & Permenkes RI \\
\hline 14. & E. Colli & $\begin{array}{l}\mathrm{CFU} / 100 \\
\mathrm{~mL}\end{array}$ & 7 & 7 & ALT & 0 & $\begin{array}{l}\text { N0. } 32 \text { Tahun } \\
2017\end{array}$ \\
\hline
\end{tabular}

Sumber : UPT Laboratorium Lingkungan, Dinas Lingkungan Hidup, Pemkab Ende, 2019 Keterangan $:=\square$ Nilai yang melampaui ambang batas maksimum yang diperbolehkan. 
Dari tabel 2, parameter Zat Padat Terlarut/Total Dissolved Solid (TDS) adalah bahan-bahan terlarut yang memiliki range diameter $10^{-6} \mathrm{~mm}-10^{-3}$ $\mathrm{mm}$ (termasuk koloid), hasil analisis laboratorium menunjukkan kandungan TDS pada sampel I jumlahnya 13 kali lebih banyak dari standar baku yang ditetapkan. Sedangkan pada sampel II jumlah TDS juga melampaui batas baku yaitu 1736 hampir 2 kali dari standar baku. TDS biasanya disebabkan oleh bahan anorganik yang biasa terdapat di daerah yang dekat dengan perairan. Wilayah kampung ujung yang berdekatan dengan laut menjadi salah satu sumber ion-ion anorganik ini. Beberapa ion tersebut bisa yang masuk dalam kelompok ion utama seperti Natrium, Kalsium, Sulfat, Bikarbonat atau kelompok ion sekunder seperti Ion Besi, Kalium, Karbonat, Nitrat, Fluorida. Berdasarkan konsentrasi TDS yang diperoleh, sampel I masuk dalam kelompok tingkat salinitas sedang/payau sedangkan sampel II memiliki tigkat salinitas agak asin/payau. Tingginya TDS kemungkinan disebabkan pelapukan batuan, limpasan dari tanah dan pengaruh antropogenik/aktivitas manusia berupa limbah domestik dan industri wisata. Tingginya nilai TDS sekalipun tidak bersifat toksik dapat meningktakan kekeruhan air yang berimplikasi menurunnya proses fotosintesis pada badan air.

Umumnya kelarutan Oksigen (Dissolved Oxygen/DO) semakin berkurang dengan meningkatnya salinitas, dari hasil analisis sampel I dan II menunjukkan kandungan Oksigen pada sampel kurang dari batas baku mutu air yang ditetapkan. Selain faktor salinitas faktor lainnya seperti pergerakan badan air, aktivitas fotosintesis, dan limbah juga berpengaruh terhadap konsentrasi Oksigen. Pada sampel I jumlah DO 3,3 $\mathrm{mg} / \mathrm{L}$, lokasi sumur berada pemukiman padat sehingga kemungkinan kurangnya aktifitas fotosintesis serta tingginya aktivitas antropogenik (digunakan sekitar 8-10 keluarga) di areal sekitar sumur menyebabkan oksigen terlarut sangat sedikit pada sampel air. Sedangkan pada sampel II, sumur hanya digunakan oleh 45 keluarga dan ruang areal sumur cukup luas sehingga kandungan Oksigennya lebih baik dibandingkan sampel I meskipun masih dibawah standar baku. Menurunnya DO bisa berpengaruh terhadap cita rasa air, air menjadi tidak segar untuk diminum.

Nitrat $\left(\mathrm{NO}_{3}{ }^{-}\right)$, Nitrit $\left(\mathrm{NO}_{2}{ }^{-}\right)$dan Ammonia $\left(\mathrm{NH}_{4}{ }^{+}\right)$termasuk dalam kelompok ion minor dalam perairan. Sumber ketiga Ion ini berasal dari proses amonifikasi yaitu pembusukkan protein dari makhluk hidup. Hasil analisis Laboratorium menunjukkan pada sampel I kandungan Nitrat melampaui standar baku, hal ini mengindikasikan terjadinya pencemaran yang berasal dari aktivitas manusia dan tinja hewan. Pada sampel II kadar Nitrit yang terdeteksi melampaui standar baku, sumber Nitrit juga kemungkinan berasal dari limbah industri wisata atau limbah domestik. Nitrit memiliki sifat lebih toksik dibandingkan Nitrat, Konsumsi Nitrit pada manusia dapat mengakibatkan terganggunya proses pengikatan oksigen oleh darah. Meskipun tidak melampaui standar baku namun kehadiran ion amonium sesuai dengan kondisi sampel air yang nilai oksigen terlarutnya kecil atau dibawah standar. Kadar ion amonium ini menunjukkan adanya pencemaran bahan organik yang berasal dari limbah domestik dan industri (pariwisata).

Parameter berikut yang digunakan untuk menentukan tingkat higienis air tanah adalah kandungan Total Colliform dan Escheria Colli . Hasil analisis sampel air sumur I dan II ditemukan kandungan E.Colli melampaui standar baku yang ditetapkan sedangkan T.Colli masih dibawah standar. E. Colli adalah bakteri dari kelompok T. Colli yang tidak berbahaya dan terdapat dalam tinja manusia. Akan tetapi konsentrasi E.Colli yang diatas standar menunjukkan bahwa air sumur telah tersebut telah tercemar oleh kotoran manusia atau hewan, yang kemungkinan besar juga mengandung bakteri patogen yang membahayakn kesehatan. Beberapa Patogen tersebut 
bisa berupa Kelompok Bakteri, Virus, Protozoa dan Helminthes.

\section{KESIMPULAN DAN SARAN}

Berdasarkan hasil analisis pengujian sampel air sumur dangkal di Kampung Ujung Labuan Bajo, secara fisik dan kimia diperoleh hasil dari lokasi sumur I dan II terdapat 4 paramter yang tidak memenuhi standar baku. Parameter tang tidak memenuhi standar adalah TDS, DO, Nitrat, dan Nitrit. Hal ini menunjukan adanya pencemaran terhadap air dangkal yang ada wilayah Kampung Ujung.

Adanya penurunan kualitas air tanah di wilayah Kampung Ujung Labuan Bajo maka dapat disarankan perlunya kerjasama Pemerintah dengan Masyarakat untuk melakukan pemantauan secara rutin tehadap kualitas air tanah di wilayah Kampung Ujung dengan cara pengecekkan di laboratorium terhadap tiga parameter yaitu fisika, kimia dan biologi, perlu adanya upaya peningkatan kesadaran masyarakat tentang sanitasi lingkungan yang baik dimulai dari tingkat rumah tangga dan lingkungan pemukiman, perlunya perhatian Pemerintah untuk mengadakan sumber air yang lain agar masyarakat tidak sepenuhnya bergantung pada air sumur gali, seperti penambahan bak-bak penampungan air baku dan diharapkan adanya studi-studi lanjutan terkait pemantauan kualitas air dengan menggunakan metode yang bervariasi sehingga data yang diperoleh akan saling melengkapi.

\section{KEPUSTAKAAN}

1. Igusman I, Purwadi DD. Pengaruh Sistem Sanitasi Terhadap Kualitas Air Sumur Dangkal Pada Perumahan Tipe Kecil Di Kota Mojokerto. Rekayasa Tek Sipil 2014;3(3):195-204.

2. Yogga ZA. The Analysis of Human Activity Impacts on the Groundwater Quality of Kaligawan Village , Blora
District. 2018;1-12. Available from: https://dspace.uii.ac.id/handle/1234 56789/13106

3. Latief AS, Wahjoedi, S. S, Suparman. Kajian Terhadap Debit dan Kualitas Air Sumur Bor Di Kelurahan Jabungan. TEKNIS [Internet] 2015;10(1):17-21. Available from: https://doi.org/10.11164/jjsps.4.1_1 56_2

4. Istipsaroh, Laili S, Zayadi H. Uji Kualitas Air Sumur Kelurahan Merjosari Kecamatan Lowokwaru Kota Malang. Biosaintropis [Internet] 2016;2(1):19-24. Available from: http://biosaintropis.unisma.ac.id/ind ex.php/biosaintropis/article/view/7 9/36

5. Ari Suseno. Studi Fisis Kualitas Air Sumur di Sekitar Kawasan Industri Makassar (KIMA) [Internet]. 2016;Available from: repositori.uinalauddin.ac.id/

6. Putra CMM. Kualitas Fisik dan Coliform Air Sumur di Dusun Nanas Kabupaten Kediri Pasca Fenomena Alam Sumur Ambles. J Kesehat Lingkung [Internet] 2018;10(4):3607. Available from: e-journal.unair.ac.id

7. Manurung $\mathrm{M}$, Ivansyah $\mathrm{O}$, Nurhasanah. Analisis Kualitas Air Sumur Bor di Pontianak Setelah Proses Penjernihan Dengan Metode Aerasi, Sedimentasi dan Filtrasi. Prism Fis 2017;5(1):45-50.

8. Peraturan Pemerintah Republik Indonesia. Peraturan Pemerintah Republik Indonesia Nomor 82 Tahun 2001. Peratur Pemerintah Republik Indones [Internet] 2001;1. Available from:

https://peraturan.bpk.go.id/Home/D etails/53103/pp-no-82-tahun-2001 
